\title{
Analysis of the Influence Factors on the Reputation of Food-Delivery Companies: Evidence from Romania
}

\author{
Nicoleta Dospinescu ${ }^{1}$, Octavian Dospinescu ${ }^{2, *}$ (D) and Maria Tatarusanu ${ }^{1}$ \\ 1 Department of Management, Marketing and Business Administration, Faculty of Economics and Business \\ Administration, Alexandru Ioan Cuza University, 700506 Iasi, Romania; dnicole@uaic.ro (N.D.); \\ tmari@uaic.ro (M.T.) \\ 2 Department of Accounting, Business Information Systems and Statistics, Faculty of Economics and Business \\ Administration, Alexandru Ioan Cuza University, 700506 Iasi, Romania \\ * Correspondence: doctav@uaic.ro
}

Received: 22 April 2020; Accepted: 14 May 2020; Published: 19 May 2020

check for updates

\begin{abstract}
In contemporary economies, reputation has become a very important factor for companies that interact directly with customers. In this context, food-delivery companies must take into account the risks associated with reputation when making operational or investment decisions. Knowing the factors that influence the perception of reputation becomes a competitive advantage for improving or even eliminating the risks related to these indicators. The aim of the study was to explain the influence level and the contribution of influence factors on the reputation of food-delivery companies in Romania. The research analyzed data from 152 respondents who are food-delivery customers from Romania, considering nine possible influencing factors. The data were analyzed in SPSS and the multivariate linear regression analysis and the multivariate analysis of variance were used. The results showed a significant relationship between the perception of reputation and influencing factors such as the quality of the food delivered, the price of the food-delivery service, the variety of the menu, the taste of the food, the perception of companions, and the quality of the electronic application. Our research only partially confirmed certain socio-demographic influences on the perception of reputation. The limitations of the research are determined by the region related to Romania and by the number of socio-demographic variables.
\end{abstract}

Keywords: reputation influencing factors; reputational risk; food-delivery reputation; Romania

\section{Introduction}

Nowadays, the online food-delivery market generates substantial revenues worldwide and has become an economic sector with increased importance. Statista's official forecast [1] shows that the volume of this market will reach over 86,000 million USD in 5 years, and the number of employees involved in this industry will increase considerably. Many researchers [2,3] have been focused on the issue of sustainability in the food-delivery industry in recent times by addressing the idea of how customers' perception about the companies' sustainability and corporate social responsibility are affecting their reputation. Some authors [4] consider that managers face many challenges, including how to make the business sustainable; as a result, References $[5,6]$ consider that a sustainable reputation is very important for companies.

Trying to find previous research on the reputation of food-delivery companies in Europe, we found that there are studies $[7,8]$ that address this issue, but the area of Eastern Europe is not covered at all. More than this, we did not identify any previous research about the situation of Romanian food-delivery companies' reputations and the influencing factors. Given this finding, the purpose of this study was 
to generate the first research on the reputation of food-delivery companies in Romania by analyzing the influencing factors.

Based on the literature review, we noticed that at the international level most research focuses on attempts to prioritize reputational factors [9], while this paper addresses the reputation of the Romanian food-delivery companies in a holistic way, analyzing the factors that influence reputation: duration of order processing, the quality of the food delivered, the price associated with the food-delivery service, attitude of delivery and support staff, the variety of the menu, the taste of the food, perception of companions, delivery method, and the quality of the electronic application.

Considering the fact that for Romania there is no previous study on the reputation of food-delivery companies and that other studies in various regions of the world have taken into account only individual factors, it is obvious that there is a need to cover this unexplored area. More specifically, the following research questions need to be addressed:

- What are the factors that influence the reputation image of food-delivery companies in Romania?

- To what extent is the reputation of food-delivery companies in Romania influenced by the independent variables?

- Starting from these research questions, the study had the following sub-objectives:

- to review existing literature on the importance of reputation of food-delivery companies,

- to examine factors influencing the reputation of food delivery in Romania, and

- to determine the importance of each factor that influences the reputation of food delivery in Romania.

Thus, we analyzed the influence that some factors-such as the quality of the food, the word-ofmouth effect, costs associated with the service provided, the quality of the electronic application, the attitude of the staff, and the waiting times - can have on the reputation of food-delivery companies in Romania. In this way, we contribute to the clear highlighting of the relationships determined by the influencing factors, offering managers a scientific tool for evaluating the potential reputational risk factors.

To achieve this purpose, the paper was structured in the following sections: introduction, review of the scientific literature (determining the factors of influence and highlighting the state of the food-delivery market in Romania, defining research hypotheses), the research methodology (variables, sampling, procedures), results and discussions, and conclusions.

\section{Background and Literature Review}

\subsection{Determinants of the Reputation for Food-Delivery Companies}

Reputation is an inclusive reflection of the responsible behavior of companies and of strategies designed and implemented, along with other intrinsic elements related to market relationships, innovation, business strategy, leadership quality, etc. The rankings made by various organizations $[10,11]$ to highlight the most responsible or sustainable companies consider multiple aspects, including respect for customers and competitors, responsible behavior towards partners from outside (stakeholders) and from inside (shareholders), and being a good citizen of the community in which they operate. Customer trust is given by corporate social responsibility and its reputation, as evidenced by several studies by authors of [12-14], and leads to increased customer loyalty [15]. One study [16] shows that a high level of economic responsibility improves their attitude and perception. According to some research $[17,18]$, companies with a good reputation attract more talented employees and generate a better level of job satisfaction due to the perception among the stakeholders from the external environment. They are perceived as suppliers of higher value products and services, the customers are more loyal, and they purchase a wider range of products and services offered by the companies. They are attractive to investors, as the market perceives them as offering sustainable growth in the future. 
In this context, reputational risk is a concept that is increasingly discussed in the literature dedicated to strategic management and marketing. It is defined as the difference between stakeholder expectations and how the company actually behaves [17]. One study [19] showed that if, for example, a company offers cheap products, but with a low level of safety in their use, and customers appreciate and expect, due to the communication, the products to have a high level of security in use, there will be a difference between the expectations of this category of stakeholders and the behavior of the company. The greater the difference, the greater the exposure to a crisis, causing damage to the company's reputation.

In this era of mobile connections and online communication between people, companies, and institutions, reputation, including online reputation, is an indispensable part of corporate strategy. Some authors [20] suggest that offline reputation and online reputation allow companies to create a positive image of the entire organization and its products and services, to create competitive advantage, to better respond to crisis risks and crisis situations, and to attract more quality employees and new customers.

Some research [21-24] concluded that reputation is based on stakeholders' perception and it can be assessed by measuring their perception; such measurement can be done directly or through the media. The differences between the expectations determined by the reputation and the reality perceived by the customers are materialized in certain attitudes, such as the purchase or boycott of the company's products. From the perspective of reputational risk, a negative reputation negatively affects the customers' attitude and intention of buying.

Given the importance of reputation in the context of modern economies, we extracted the factors that influence the reputations of active companies in the field of food delivery in Romania from the studies performed in the specialized literature. This approach was justified by the fact that at the global level, there is a certain scientific concern regarding the reputation of food-delivery companies. Modern economies are becoming more and more sophisticated; they are increasingly relying on the added-value obtained as a result of providing services and, in this context, the food-delivery field is gaining major importance both economically and socially.

According to a study [25] in India, the reputation of food-delivery companies is based on factors like the speed of delivery, the kindness of the delivery person, and the prompt resolution of complaints. Reference [26] also demonstrates that the customer waiting time and the attitude of the delivery staff are determining factors for the perception of reputation. These aspects complement the results of other studies [27-29] regarding the characteristics of human resources in the field of HoReCa.

In the United States of America, Reference [30] showed that the safety offered by the primary food supplier and the traceability of food are of major importance for customer perception and implicitly for the company's reputational values. In the same line of ideas, the scientific study carried out in Reference [31] shows that the pressure of civil society has determined the adoption of food quality standards, standards that are also found in the reputational concept of food-delivery companies. In addition, References [32,33] also show that reputation is directly dependent on the quality of the food delivered. Somewhat paradoxically, Reference [33] also shows that customer loyalty to food-delivery companies is influenced by the quality of the food but does not depend on the quality of the electronic service. On the other hand, Reference [34] highlighted that the users of food-delivery services are interested in the electronic applications offered by the delivery companies in terms of functionality and ease of use regarding orders, payment, and order management. This interest is confined to the general trend described by the authors of $[35,36]$ regarding electronic services for the business environment.

In addition to the quality of food, the authors of [37] have shown that in the United States of America the reputation of the companies in the field of food delivery depends largely on the taste of the food. Also, the perception of the general image of the company is also influenced by the word-of-mouth type effect, that is, the general perception/impression of those in the client's social circle, according to References [37-39]. The importance of taste similarity with previous experiences in the case of 
frequent consumers was also highlighted by Reference [32] in a study related to the preferences of Asian customers.

Reference [40] shows that the companies that deliver food through online applications base their reputational foundation on the time savings that customers make and on the low costs associated with the service provided. The price paid by the customer for food-delivery services is an important factor in Reference [32].

Another factor influencing reputation is the degree of diversification of the menu offered; thus, Reference [37] shows that traditional franchises, established in the food field, have a stronger reputation than the companies that include new or heavily segmented food variants in menus. Reference [26] shows that the variety of menus is a factor that ensures the reputational success in the field of prepared foods.

In the context of modern technologies, Reference [38] reveals that, at present, the reputation image of food-delivery companies is also perceived by consumers through the order delivery method. Thus, the authors of [41,42] show that more and more customers in North America and Asia are aware of the option of delivery via drones. On the other hand, research [43] carried out in South America shows that the delivery method has no impact on consumers' perception of the company's reputation.

From the analysis of the specialized literature, we highlight in Table 1 the following determining indicators that are able to influence the reputation level of food-delivery companies.

Table 1. Factors of reputational influence for food-delivery companies.

\begin{tabular}{|c|c|c|}
\hline Factor & Description/Components & Previous Research \\
\hline Duration of order processing & $\begin{array}{c}\text { Time savings, order pick-up time, delivery speed, } \\
\text { waiting time }\end{array}$ & {$[25,26,40]$} \\
\hline Food quality & $\begin{array}{l}\text { The origin of the food delivered, the traceability of } \\
\text { the delivery }\end{array}$ & [30-33] \\
\hline $\begin{array}{l}\text { The price associated with the food-delivery } \\
\text { service }\end{array}$ & $\begin{array}{l}\text { The cost of the orders, the cost of the transport, } \\
\text { additional taxes, the price of the delivered food }\end{array}$ & {$[32,40]$} \\
\hline Attitude of delivery and support staff & $\begin{array}{c}\text { Taking orders, resolving complaints, informing } \\
\text { customers }\end{array}$ & {$[25,26]$} \\
\hline The variety of the menu & The degree of diversification of the menu offered & {$[26,37]$} \\
\hline The taste of the food & $\begin{array}{l}\text { Specific taste, taste similarity to previous } \\
\text { experiences }\end{array}$ & {$[32,37]$} \\
\hline The perception of companions & The word-of-mouth effect & {$[37,38]$} \\
\hline Delivery method & $\begin{array}{l}\text { Conventional (motorbike), eco (bicycle), } \\
\text { unconventional vehicles (drone) }\end{array}$ & {$[38,41-43]$} \\
\hline Quality of the electronic application & $\begin{array}{l}\text { Accessibility, ease of use, possibility of } \\
\text { configuration and customization }\end{array}$ & {$[33,34]$} \\
\hline
\end{tabular}

Sources: authors' elaboration based on specialized literature.

\subsection{Aspects of the Food-Delivery Market in Romania}

One of the largest businesses in the hospitality industry is food delivery, which has seen considerable development trends in recent years, due to digital technologies and online platforms. At the European level, there is a level of annual growth of the food-delivery market on average by $10 \%$. According to Reference [44], in Romania, there are many players in this still unsaturated market, players at the beginning of the wave and challenged to respond to increasing orders. Specialized sources [45] even mention increases of $130 \%$ compared to the previous year (2018). The Romanian market is not atypical because consumer preferences are only slightly different from those existing at the international level. What is very different is the degree of maturity of the market or the degree of custom. Technological progress and the increasingly limited time of workers significantly encourage the food-delivery segment. According to Reference [46], the target audience are millennials (24-35 years old) who are the main customers that stimulate market activity at the national level. The important aspects that encourage them to order online are the multitude of cuisines from fine, selective menus to fast food options. In the specialized literature [46], it was observed that there is a trend related to the 
preference for miscellaneous international food (such as Asian or Latin American food), ordered in a proportion of $80 \%$. Another trend refers to the preference for natural, organic products.

Following the analysis of previous results from the literature, we noticed that there is no clear and complete picture of the factors that influence the reputation of food-delivery companies. It is also worth noting that in some countries or regions certain influencing factors predominate, while in other areas there are other factors. The studies already performed refer only to sequences of 2-3 factors, without considering a holistic approach. Moreover, there are no such studies that include Romania. As a result, through our research, we wanted to cover this gap with a more comprehensive analysis of the factors influencing the reputation of food-delivery companies in Romania.

\subsection{Aims and Hypotheses}

The aim of this study was to explain the influence level and the contribution of several factors on the reputations of food-delivery companies in Romania. These factors are (1) duration of order processing, (2) the quality of the food delivered, (3) the price associated with the food-delivery service, (4) attitude of delivery and support staff, (5) the variety of the menu, (6) the taste of the food, (7) perception of companions, (8) delivery method, and (9) the quality of the electronic application. Based on the previous research from the literature review and the results from Table 1, the initial hypothesis was that all these factors have a significant influence on the reputation perceived by customers of food-delivery companies. In addition to this main hypothesis, we also tested the dependence of these factors on some socio-demographic variables like gender, age, and education level.

As we have presented in the synthesis of the specialized literature Table 1, the previous studies focused only on some of these factors or on limited groups of influence indicators. Thus, the present article becomes important because it carried out an exhaustive analysis of the factors of influence on the reputation of food-delivery companies and in the scientific systematization of these indicators. In this way, we aimed to obtain a more comprehensive picture of the determinants of reputation. As a result, in our article, the selected factors were those which had a certain level of significance. Each of the indicators we selected based on the specialized literature was evaluated in the form of an individual hypothesis, according to the data presented in Table 2.

Table 2. The main research hypotheses.

\begin{tabular}{|c|c|}
\hline Hypothesis & Hypothesis Description \\
\hline $\mathrm{H} 1$ & $\begin{array}{l}\text { The duration of the order processing has a significant impact on the } \\
\text { food-delivery consumers' perception of reputation. }\end{array}$ \\
\hline $\mathrm{H} 2$ & $\begin{array}{l}\text { The quality of the delivered food has a significant impact on the } \\
\text { food-delivery consumers' perception of reputation. }\end{array}$ \\
\hline H3 & $\begin{array}{l}\text { The price associated with the food-delivery service has a significant } \\
\text { impact on the food-delivery consumers' perception of reputation. }\end{array}$ \\
\hline H4 & $\begin{array}{l}\text { The attitude of the delivery and support staff has a significant impact on } \\
\text { the food-delivery consumers' perception of reputation. }\end{array}$ \\
\hline H5 & $\begin{array}{l}\text { The variety of the menu has a significant impact on the food-delivery } \\
\text { consumers' perception of reputation. }\end{array}$ \\
\hline H6 & $\begin{array}{l}\text { The taste of the delivered food has a significant impact on the } \\
\text { food-delivery consumers' perception of reputation. }\end{array}$ \\
\hline $\mathrm{H} 7$ & $\begin{array}{l}\text { The perception of companions has a significant impact on the } \\
\text { food-delivery consumers' perception of reputation. }\end{array}$ \\
\hline $\mathrm{H} 8$ & $\begin{array}{l}\text { Order delivery method has a significant impact on the food-delivery } \\
\text { consumers' perception of reputation. }\end{array}$ \\
\hline H9 & $\begin{array}{l}\text { The quality of the electronic application has a significant impact on the } \\
\text { food-delivery consumers' perception of reputation. }\end{array}$ \\
\hline
\end{tabular}

Source: authors' elaboration based on the following studies [25,26,30-34,37,38,40-43].

In addition, the characteristics of different demographic aspects could generate different perceptions of customers on different segments. In this context, we proposed the group of additional hypotheses from Table 3. 
Table 3. Additional research hypotheses.

\begin{tabular}{|c|c|}
\hline Hypothesis & Hypothesis Description \\
\hline Ha1 & $\begin{array}{c}\text { The reputation perceived by the customers of food-delivery companies } \\
\text { differs significantly according to their age. }\end{array}$ \\
\hline Ha2 & $\begin{array}{l}\text { The reputation perceived by the customers of food-delivery companies } \\
\text { differs significantly according to their gender. }\end{array}$ \\
\hline На3 & $\begin{array}{l}\text { The reputation perceived by the customers of food-delivery companies } \\
\text { differs significantly depending on their level of education. }\end{array}$ \\
\hline
\end{tabular}

Source: authors' elaboration based on the following studies [45,46].

\section{Research Methodology}

\subsection{Variables and Instruments}

The present research included many variables that were taken into account in order to support or reject the sets of research hypotheses. We also defined the variables age, gender, and level of education as being the independent grouping variables in our research. The independent variables were of interval type (value scale) and included the duration of the order processing, the quality of the delivered food, the price associated with the food-delivery service, the attitude of the delivery and support staff, the variety of the menu, the taste of the food delivered, the perception of companions, the delivery method, and the quality of the electronic application.

The reputation perceived by the customers of food-delivery companies from Romania was analyzed on the basis of a survey comprising 14 questions:

- the main analyzed factors were covered by 9 questions of the survey and

- the criteria used to filter the respondents and to get the demographic characteristics were covered by 5 questions.

The subjects were asked to rate each of the factors analyzed for reputation on a Likert-type scale with values from 1 to 5 ; value (score) 1 indicated that the respective indicator had no effect on the customer's perception of the reputation of the food-delivery company, while value 5 indicated that the customer attached a very high level of importance to the company's reputation.

After collecting the data, a reliability test was conducted in SPSS in order to check the internal consistency. The value of Cronbach's alpha based on standardized items was 0.632 (number of items $=9$ ). According to Reference [47], this value means that the internal consistency of the survey was acceptable and the reliability was quite high. The validity of the questionnaire was tested by applying Pearson product-moment correlation (PPMC). The PPMC values were significant at 0.05 level (2-tailed) for $\mathrm{N}=152$.

\subsection{Sample}

The research we conducted included 152 respondents. The number of respondents was relevant because, according to data provided by Raosoft [48], the minimum number of subjects must be 139 for a $95 \%$ confidence level. Based on this minimum number, we distributed the questionnaire to 181 respondents. Of these, 29 respondents gave invalid answers, so that 152 questionnaires remained valid for our analysis. Of the total respondents analyzed, $51.31 \%$ were over the age of 25 (millennials) and $48.69 \%$ were under the age of 25 (generation Z), $61.84 \%$ were female and $38.16 \%$ were male. Regarding the level of education, $58.55 \%$ had university studies, $5.92 \%$ had high school diplomas and $35.53 \%$ had postgraduate studies.

\subsection{Procedure and Analysis of Data}

The survey was conducted in Romania in December 2019, January 2020, and February 2020. The questionnaire was distributed electronically to persons aged between 18 and 45, and the data 
obtained from the subjects were described by the values of descriptive statistics (mean values, deviation). Data processing was performed using the IBM SPSS Statistics statistical processing tool version 21. To verify the research hypotheses that we established after the analysis of the literature, we used several statistical analyzes: Pearson correlation, multivariate analysis of variation, and the model of multiple linear regression analysis.

Our research aimed to highlight an econometric model regarding the factors influencing the reputation of food-delivery companies. Starting from the nine research hypotheses identified following the analysis of the literature, our study econometrically modeled the relationships between independent variables and the reputational image. Previous studies [25,26,30-34,37,38,40-43] have considered only partial research on influencing factors; we aimed to obtain a global picture of these influences through the multiple linear regression model because this model significantly reflects individual influences in a generalized context.

\section{Results and Discussions}

Our research aimed to obtain multiple linear regression coefficients in order to model the factors influencing the reputation of food-delivery companies. The calculations were performed using SPSS and we present below the results regarding the descriptive statistics for the independent and dependent variables, the contribution of independent variables in describing the reputation of food-delivery companies, and the contribution of demographic factors in predicting dependent variables.

In Table 4, there are presented the values of descriptive statistics for the nine independent factors and for the dependent variable (the reputation level perceived by the customers of the food-delivery companies).

Table 4. The values of the descriptive statistics for the independent variables and the dependent variable for the food-delivery companies.

\begin{tabular}{cccccc}
\hline Indicators & $\mathbf{N}$ & Minimum & Maximum & Media & Standard Deviation \\
\hline Duration of Order Processing & 152 & 1.00 & 5.00 & 4.1447 & 0.65580 \\
Quality of Food Delivered & 152 & 2.00 & 5.00 & 3.8421 & 0.71333 \\
Price & 152 & 1.00 & 5.00 & 3.5461 & 1.23866 \\
Staff Attitude & 152 & 2.00 & 5.00 & 4.6579 & 0.61013 \\
Variety of Menu & 152 & 2.00 & 5.00 & 4.2368 & 0.54423 \\
Taste of Food & 152 & 1.00 & 5.00 & 2.3947 & 1.27200 \\
Companions Perception & 152 & 1.00 & 5.00 & 4.6053 & 0.73609 \\
Delivery Method & 152 & 1.00 & 5.00 & 4.2434 & 0.78053 \\
Quality of Electronic Application & 152 & 2.00 & 5.00 & 4.4046 & 0.59449 \\
Reputation Level & 152 & 3.00 & 5.00 & 4.2895 & 0.60496 \\
\hline
\end{tabular}

The perceived reputation level was largely affected by the attitude of the staff $(\mathrm{M}=4.65)$, the perception of companions ( $M=4.60)$, the quality of the electronic application $(M=4.40)$, and the delivery method $(\mathrm{M}=4.24)$. Based on the average of the answers in the questionnaire, the level of reputation was affected to a lesser extent by the quality of the food delivered $(M=3.84)$, the price of the food-delivery service $(M=3.54)$, and the taste of the food $(M=2.39)$. These values confirmed some of the previous research conducted in the specialized literature regarding the attitude of the staff $[25,26]$, the quality of the electronic application [33,34], and delivery method [38,41-43].

In order to test hypotheses $\mathrm{H} 1-\mathrm{H} 9$, we used multiple linear regression analysis in which the dependent variable was the perception of reputation, and the independent variables were duration of order processing, quality of food delivered, price of food-delivery service, staff attitude, menu variety, taste of food, perception of companions, method of delivery, and the quality of electronic application. We chose the multiple linear regression model because this model significantly reflects the influences of the individual factors on reputation. The linear association model was performed and the Enter method was used, which included all variables in the multiple linear regression model. Following the calculations, the data from Table 5 were obtained, the values in the Beta column represent the standardized values of the coefficients. Although in some scientific papers [49] a level of significance 
threshold of $10 \%$ is accepted, in our research the values of the coefficients for which the significance threshold is less than $5 \%$ were considered relevant in the elaboration of the econometric model.

Table 5. The contribution of independent variables in describing the reputation of food-delivery companies.

\begin{tabular}{cccc}
\hline Indicators & Standardized Beta & $\mathbf{t}$ & Sig. \\
\hline Duration of Order Processing & -0.098 & -1.698 & 0.092 \\
Quality of Food Delivered & $0.130^{*}$ & 2.065 & 0.041 \\
Price & $-0.126^{*}$ & -2.452 & 0.015 \\
Staff Attitude & 0.002 & 0.027 & 0.979 \\
Variety of Menu & $0.354^{* *}$ & 5.703 & 0.000 \\
Taste of Food & $0.121^{*}$ & 2.299 & 0.023 \\
Companions Perception & $0.578^{* *}$ & 10.629 & 0.000 \\
Delivery Method & 0.082 & 1.490 & 0.138 \\
Quality of Electronic Application & $0.131^{*}$ & 2.290 & 0.024 \\
\hline
\end{tabular}

We noted that after calculations based on statistical data, the value of adjusted R-squared is 0.658 , and $\mathrm{F}=33.228, p<0.01$. These values led us to conclude that reputation was statistically significantly determined by some of the indicators analyzed. This conclusion was also confirmed by the data in Table 6 where are the results of the multicollinearity test of the explanatory variables (variance inflation factor (VIF)).

Table 6. Statistics of the multicollinearity test (variance inflation factor (VIF)).

\begin{tabular}{ccc}
\hline Indicator & Tolerance & VIF \\
\hline Duration of Order Processing & 0.679 & 1.473 \\
Quality of Food Delivered & 0.571 & 1.750 \\
Price & 0.862 & 1.161 \\
Staff Attitude & 0.646 & 1.548 \\
Variety of Menu & 0.589 & 1.698 \\
Taste of Food & 0.819 & 1.221 \\
Companions Perception & 0.766 & 1.305 \\
Delivery Method & 0.753 & 1.327 \\
Quality of Electronic Application & 0.694 & 1.442 \\
\hline
\end{tabular}

The fact that all the VIF values were lower than 2.00 certifies the lack of collinearity of the variables and constitutes an additional argument for justifying the validity of the model.

Regarding the contributions of the indicators in determining the reputational image of food-delivery companies, based on the data in Table 5, we noticed that this was positively influenced by the quality of the food delivered (Beta $=0.130$ ), the variety of the menu (Beta $=0.354$ ), the taste of the food (Beta $=0.121)$, the perception of companions (Beta $=0.578)$, and the quality of the electronic application (Beta $=0.131)$.

Based on the obtained results, we concluded that the research hypotheses $\mathrm{H} 2, \mathrm{H} 3, \mathrm{H} 5, \mathrm{H} 6, \mathrm{H} 7$, and $\mathrm{H} 9$ were supported. This means that the relationships regarding the indicators like the quality of food, the price associated with the food-delivery service, the variety of the menu, the taste of the food, the perception of companions, and the quality of the electronic application were confirmed. The hypotheses were not supported for the indicators regarding the duration of the order processing, the attitude of the staff, and the method of delivery.

To test the set of additional hypotheses Ha1-Ha3, a multivariate analysis of the variance was implemented in order to see if the level of the reputation in terms of the duration of order processing, the quality of the delivered food, the price associated with the food-delivery service, the attitude of the staff, the variety of the menu, the taste of the food, the perception of companions, the delivery method, 
and the quality of the electronic application depended on some specific socio-demographic factors, specifically gender, age, level of education.

The data and the significance thresholds in Table 7 show that Ha1 and Ha2 were only partially supported; the same data shows that $\mathrm{Ha} 3$ was not confirmed. Age generated statistically significant differences for order processing variables $(\mathrm{F}=5.784, p<0.05)$, quality of food delivered $(\mathrm{F}=7.444$, $p<0.01)$, and quality of electronic application $(\mathrm{F}=2.733, p<0.10)$. Gender generated statistically significant differences for the order processing variables $(\mathrm{F}=6.721, p<0.05)$, menu variety $(\mathrm{F}=9.850$, $p<0.01)$, delivery method $(\mathrm{F}=7.529, p<0.01)$, and quality of electronic application $(\mathrm{F}=3.944, p<0.05)$. The level of education did not generate any statistically significant difference for the variables analyzed in the model proposed in this article.

Table 7. The contribution of demographic factors in predicting dependent variables.

\begin{tabular}{|c|c|c|c|}
\hline \multicolumn{2}{|c|}{ Source/Dependent Variable } & \multirow{2}{*}{$\frac{\mathbf{F}}{5.784^{* *}}$} & \multirow{2}{*}{$\begin{array}{c}\text { Sig. } \\
0.017\end{array}$} \\
\hline Age & Duration of Order Processing & & \\
\hline & Quality of Food Delivered & $7.444^{* * *}$ & 0.007 \\
\hline & Price & 0.084 & 0.773 \\
\hline & Staff Attitude & 1.012 & 0.316 \\
\hline & Variety of Menu & 0.199 & 0.656 \\
\hline & Taste of Food & 1.007 & 0.317 \\
\hline & Companions Perception & 0.176 & 0.676 \\
\hline & Delivery Method & 0.182 & 0.670 \\
\hline & Quality of Electronic Application & $2.733^{* * *}$ & 0.100 \\
\hline \multirow[t]{9}{*}{ Gender } & Duration of Order Processing & $6.721^{* *}$ & 0.011 \\
\hline & Quality of Food Delivered & 0.011 & 0.915 \\
\hline & Price & 0.163 & 0.687 \\
\hline & Staff Attitude & 1.431 & 0.234 \\
\hline & Variety of Menu & $9.850 * * *$ & 0.002 \\
\hline & Taste of Food & 0.018 & 0.895 \\
\hline & Companions Perception & 0.073 & 0.788 \\
\hline & Delivery Method & $7.529^{* * *}$ & 0.007 \\
\hline & Quality of Electronic Application & $3.944^{* *}$ & 0.049 \\
\hline \multirow[t]{9}{*}{ Education level } & Duration of Order Processing & 2.233 & 0.111 \\
\hline & Quality of Food Delivered & 1.447 & 0.239 \\
\hline & Price & 2.180 & 0.117 \\
\hline & Staff Attitude & 1.737 & 0.180 \\
\hline & Variety of Menu & 0.107 & 0.899 \\
\hline & Taste of Food & 0.047 & 0.954 \\
\hline & Companions Perception & 1.134 & 0.325 \\
\hline & Delivery Method & 1.165 & 0.315 \\
\hline & Quality of Electronic Application & 0.120 & 0.887 \\
\hline
\end{tabular}

Note: ${ }^{*}$ significant for $10 \%$ level, ${ }^{* *}$ significant for $5 \%$ level, ${ }^{* * *}$ significant for $1 \%$ level.

Based on the analyzes carried out in the present study, it was demonstrated that the reputation of the food-delivery companies was significantly influenced by the following indicators: the quality of the food delivered, the price of the food-delivery service, the variety of the menu, the taste of the food, the perception of companions, and the quality of the electronic application. The linear regression equation containing only the statistically relevant indicators can be expressed as follows:

$$
\mathrm{Y}=0.130 * \mathrm{X} 1-0.126 * \mathrm{X} 2+0.354 * \mathrm{X} 3+0.121 * \mathrm{X} 4+0.578 * \mathrm{X} 5+0.131 * \mathrm{X} 6
$$

where:

$\mathrm{X} 1$ = the quality of the food delivered;

$\mathrm{X} 2$ = the price of the food-delivery service;

$\mathrm{X} 3$ = the variety of the menu; 
$\mathrm{X} 4=$ the taste of the food;

$\mathrm{X} 5=$ the perception of companions; and

$\mathrm{X} 6=$ the quality of the electronic application.

Also, the results showed that of the analyzed demographic factors, only gender and age generated statistically significant differences regarding the perception of the reputational image of food-delivery companies. The aggregated results of the research can be a scientific basis for addressing reputational risk factors for these companies.

Our study considered nine potential factors for the reputation of food-delivery companies in Romania. Previous studies in the literature have shown that in various countries and regions, some of these factors have different influences on the overall reputation of companies. The results obtained by us showed that in Romania, the reputation of food-delivery companies was significantly influenced by the following variables: the quality of the food delivered, the price, the variety of the menu, the taste of the food, the perception of companions, and the quality of the electronic application. These results confirm the partial results obtained by References $[26,30-34,37,38,40]$, which means that food-delivery companies from Romania must pay particular attention to these six aspects when considering the construction and improvement of their reputational image. On the other hand, our research highlighted the fact that three of the factors-duration of order processing, staff attitude and delivery method - had no significant impact on the reputation of food-delivery companies in Romania. These results obtained by us were different from the results of research conducted by References $[25,26,38,40-43]$, which means that the food-delivery market in Romania has its own specificities and Romanian managers do not have to allocate important resources for these aspects related to reputation.

\section{Conclusions}

Our article aimed to highlight the factors that really influence the reputational image of food-delivery companies in Romania. Based on the literature, we extracted nine factors that could be relevant and analyzed them using the multiple linear regression model. Our research found that in Romania the following six factors were important for the reputation of food-delivery: the quality of the food delivered, the price, the variety of the menu, the taste of the food, the perception of companions, and the quality of the electronic application. These findings confirmed the partial results obtained by References $[26,30-34,37,38,40]$. At the same time, in Romania, there were three factors that did not have any statistically significant influence on the reputation. These findings were in contradiction with the results obtained by References [25,26,38,40-43]. From a demographic point of view, reputation in Romania depended only on age and gender, while the level of education did not have a significant influence on the perception of reputation.

These results that we obtained through our research are useful for managers who deal with the management of the image of food-delivery companies in Romania because our findings offer accurate information about the factors that are really relevant.

As we mentioned in the article, the food-delivery market in Romania is effervescent, competitive, and constantly growing. The results obtained through our study provided realistic information for the managers of food-delivery companies in Romania. The list of factors influencing reputation can be considered for the improvement of brand reputation. Based on the six influencing factors that were highlighted in the research, companies can build brands that differentiate themselves from competitors and position themselves on the market.

Market segmentation by age and gender is essential for adapting, positioning, and differentiating products and services, but also for their specific communication. Thus, food-delivery companies from Romania will be able to concentrate their efforts to define their brands centered on factors such as the quality of the food delivered, the price, the variety of the menu, the taste of the food, the perception of companions, and the quality of the electronic application.

According to the results obtained by our study, it was observed that at the level of Romanian society, one of the factors influencing reputation was the quality of the electronic application. This means that 
consumers tended to migrate to new information technologies when using food-delivery services. As a result, food-delivery companies in Romania must focus on this new societal trend and adapt their communication about services and products to the new behavior of consumers. In this way, companies can fulfill the desideratum of the concept of engagement marketing by including a part of society with the help of electronic applications and the influence of companions. Thus, a specific affinity of the company towards the brand is generated, making it more reliable in a competitive society.

Given the importance of the food-delivery industry, the entire society will sustainably benefit from the results of our research because customer-supplier relationships can be improved based on knowledge of the issues highlighted in this article. The marketing efforts of food-delivery companies in Romania will be able to be carried out in the right directions, focusing mainly on the factors that really have an influence on the reputation perceived by customers.

In order to present the limitations of the article, we consider relevant to highlight that the research we have done is territorially limited to the level of food-delivery companies in Romania. Also, another limitation is given by the fact that in our analysis we studied only nine indicators regarding the reputational image and only three socio-demographic factors.

Based on the results obtained in the present study, the following future directions can be identified: the analysis of the food-delivery companies comparatively, on several countries and possibly geographical regions; the analysis of the perception of reputation according to many relevant indicators; and the inclusion of other socio-demographic factors in comparative analysis.

Author Contributions: Conceptualization, N.D. and O.D.; methodology, O.D. and N.D.; software, O.D.; validation, N.D., O.D., and M.T.; formal analysis, O.D.; investigation, N.D. and M.T..; resources, N.D. and M.T.; writing—original draft preparation, O.D., N.D., and M.T.; writing—review and editing, N.D., O.D., and M.T. All authors have read and agreed to the published version of the manuscript.

Funding: This research received no external funding.

Conflicts of Interest: The authors declare no conflict of interest.

\section{References}

1. Blumtritt, C. Revenue Forecast for the Online Food Delivery Market Worldwide until 2024; Statista: Hamburg, Germany, 2020.

2. Kim, S.; Yoon, J.; Choi, I. What matters to promote consumers' intention to patronize sustainable business-and-industry (B\&I) food services? Br. Food J. 2016, 118, 2710-2731.

3. Chandrasekhar, N.; Saloni, G.; Nanda, N. Food Delivery Services and Customer Preference: A Comparative Analysis. J. Foodserv. Bus. Res. 2019, 22, 375-386. [CrossRef]

4. Høgevold, N.; Svensson, G.; Wagner, B.; Petzer, D.; Klopper, H.; Varela, J.C.S.; Padin, C.; Ferro, C. Sustainable business models: Corporate reasons, economic effects, social boundaries, environmental actions and organizational challenges in sustainable business practices. Balt. J. Manag. 2014, 9, 357-380. [CrossRef]

5. Zetterlund, H.; Hallstedt, S.; Broman, G. Implementation Potential of Sustainability-oriented Decision Support in Product Development. Procedia Cirp 2016, 50, 287-292. [CrossRef]

6. Tong, C.; Wong, A.; Cheng, T. Do Corporate Social Responsibility and Safety of Food Affect Reputation? A Study of Fast-food Restaurants Industry in Hong Kong. J. Econ. Manag. Trade 2019, 22, 1-18. [CrossRef]

7. Dablanc, L.; Morganti, E.; Arvidsson, N.; Woxenius, J.; Browne, M.; Saidi, N. The rise of on-demand 'Instant Deliveries' in European cities. Supply Chain Forum 2018, 18, 203-217. [CrossRef]

8. Finotto, V.; Marrone, M. Challenging Goliath. Informal Unionism and Digital Platforms in the Food Delivery Sector. The Case of Riders Union Bologna. Partecip. E Confl. 2019, 12, 691-716.

9. Benn, S.; Abratt, R.; Kleyn, N. Reducing reputational risk: Evaluating stakeholder salience and prioritising stakeholder claims. Mark. Intell. Plan. 2016, 34, 828-842. [CrossRef]

10. Global Reporting Initiative. The GRI Standards: The Global Standards for Sustainability Reporting; Global Reporting Initiative: Amsterdam, The Netherlands, 2016.

11. Corporate Knights. Most Sustainable Corporations in World. Global 100. The 2020 Global 100: Overview of Corporate Knights Rating Methodology; Global100.org: Toronto, ON, Canada, 2020. 
12. Agarwal, J.; Osiyevskyy, O.; Feldman, P. Corporate Reputation Measurement: Alternative Factor Structures, Nomological Validity, and Organizational Outcomes. J. Bus. Ethics 2014, 130, 485-506. [CrossRef]

13. Keh, H.; Xie, Y. Corporate reputation and customer behavioral intentions: The roles of trust, identification and commitment. Ind. Mark. Manag. 2009, 38, 732-742. [CrossRef]

14. Park, J.; Lee, H.; Kim, C. Corporate social responsibilities, consumer trust and corporate reputation: South Korean consumes' perspectives. J. Bus. Res. 2014, 67, 295-302. [CrossRef]

15. Marin, L.; Ruiz, S.; Rubio, A. The role of identity salience in the effects of corporate social responsibility on consumer behaviour. J. Bus. Ethics 2009, 84, 65-78. [CrossRef]

16. Park, J. Corporate social responsibility as a determinant of corporate reputation in the airline industry. J. Retail. Consum. Serv. 2019, 47, 215-221. [CrossRef]

17. Eccles, R.; Newquist, S.; Schatz, R. Reputation and its risks. Harv. Bus. Rev. 2007, 85, 104-114.

18. Riordan, C.; Gatewood, R.; Bill, J. Corporate image: Employee reactions and implications for managing corporate social performance. J. Bus. Ethics 1997, 16, 401-412. [CrossRef]

19. Pèrez, C.; Estherde, C.; Puento, E.Q.; Garcia, J.D. How to Manage Corporate Reputation? The effect of Enterprise Risk Management Systems and Audit Committees on Corporate Reputation. Eur. Manag. J. 2019, 37, 505-515. [CrossRef]

20. Zraková, D.; Demjanovičová, M.; Kubina, M. Online reputation in the transport and logistics field. Transp. Res. Procedia 2019, 40, 1231-1237. [CrossRef]

21. Aksak, E.; Ferguson, M.; Duman, S. Corporate social responsibility and CSR fit as predictors of corporate reputation: A global perspective. Public Relat. Rev. 2016, 42, 79-81. [CrossRef]

22. Jung, N.; Seock, Y. The impact of corporate reputation on brand attitude and purchase intention. Fash. Text. 2016, 3, 20. [CrossRef]

23. Galbreath, J.; Shum, P. Do customer satisfaction and reputation mediate the CSR-FP link? Evidence from Australia. Aust. J. Manag. 2012, 37, 211-229. [CrossRef]

24. Castaldo, S.; Perrini, F.; Misani, N.; Tencati, A. The missing link between corporate social responsibility and consumer trust: The case of fair trade products. J. Bus. Ethics 2009, 84, 1-15. [CrossRef]

25. Ghosh, A.; Dana, S.; Sharma, A.; Das, S. A Study on Consumers Preference and Satisfaction towards Ready-to-eat Fish Products in West Bengal, India. Fish. Technol. 2018, 55, 282-287.

26. Law, A.; Hui, Y.; Zhao, X. Modeling repurchases frequency and customer satisfaction for fast food outlets. Int. J. Qual. Reliab. Manag. 2004, 21, 545-563. [CrossRef]

27. Butnaru, G.; Miller, A.; Nita, V.; Stefanica, M. A new approach on the quality evaluation of tourist services. Econ. Res. 2018, 31, 1418-1436. [CrossRef]

28. Gligor-Cimpoieru, D.; Munteanu, V.; Nitu-Antonie, R.; Schneider, A.; Preda, G. Perceptions of Future Employees toward CSR Environmental Practices in Tourism. Sustainability 2017, 9, 1631. [CrossRef]

29. Nita, V.; Agheorghiesei, D. The perception of the students specializing trade, tourism and services on the importance of the concept of sustainable development in commercial activities. Amfiteatru Econ. 2010, 12, 66-82.

30. Pouliot, S.; Sumner, D. Traceability, recalls, industry reputation and product safety. Eur. Rev. Agric. Econ. 2013, 40, 121-142. [CrossRef]

31. Fulponi, L. Private voluntary standards in the food system: The perspective of major food retailers in OECD countries. Food Policy 2006, 31, 1-13. [CrossRef]

32. Islam, N.; Ullah, G. Factors Affecting Consumers' Preferences on Fast Food Items in Bangladesh. J. Appl. Bus. Res. 2010, 26, 131. [CrossRef]

33. Suhartanto, D.; Ali, M.H.; Tan, K.H.; Sjahroeddin, F.; Kusdibyo, L. Loyalty toward online food delivery service: The role of e-service quality and food quality. J. Foodserv. Bus. Res. 2019, 22, 81-97. [CrossRef]

34. Pigatto, G.; Machado, J.; Negreti, A.; Machado, L. Have you chosen your request? Analysis of online food delivery companies in Brazil. Br. Food J. 2017, 119, 639-657. [CrossRef]

35. Dănăiaţă, D.; Margea, C.; Hurbean, L.; Artene, A. Electronic Services for Business Environment. Procedia Soc. Behav. Sci. 2014, 124, 351-360.

36. Necula, S.; Pavaloaia, V.; Strimbei, C.; Dospinescu, O. Enhancement of E-Commerce Websites with Semantic Web Technologies. Sustainability 2018, 10, 1955. [CrossRef]

37. Min, H.; Min, H. Benchmarking the service quality of fast-food restaurant franchises in the USA: A longitudinal study. Benchmarking Int. J. 2011, 18, 282-300. [CrossRef] 
38. Hwang, J.; Kim, H. Consequences of a green image of drone food delivery services: The moderating role of gender and age. Bus. Strategy Environ. 2019, 28, 872-884. [CrossRef]

39. Anastasiei, B.; Dospinescu, N. A model of the relationships between the Big Five personality traits and the motivations to deliver word-of-mouth online. Psihologija 2018, 51, 215-227. [CrossRef]

40. Yeo, V.C.S.; Goh, S.-K.; Rezaei, S. Consumer experiences, attitude and behavioral intention toward online food delivery (OFD) services. J. Retail. Consum. Serv. 2017, 35, 150-162. [CrossRef]

41. Pepitone, J. Domino's Tests Drone Pizza Delivery. Available online: http://money.cnn.com/2013/06/04/ technology/innovation/dominos-pizza-drone/index.html (accessed on 6 February 2020).

42. Hwang, J.; Kim, H.; Kim, W. Investigating motivated consumer innovativeness in the context of drone food delivery services. J. Hosp. Tour. Manag. 2019, 38, 102-110. [CrossRef]

43. Correa, J.; Garzon, W.; Brooker, P.; Sakarkar, G.; Carranza, S.; Yunado, L.; Rincon, A. Evaluation of collaborative consumption of food delivery services through web mining techniques. J. Retail. Consum. Serv. 2019, 46, 45-50. [CrossRef]

44. Davtchev, V. Interviewee, Food Delivery Romanian Market [Interview]. 1211 2019. Available online: https://www.forbes.ro/vladimir-davtchev-regional-director-south-east-europe-takeaway-com-romaniadesi-exista-multi-jucatori-piata-de-food-delivery-se-afla-inca-la-inceput-si-exista-loc-de-crestere-149268 (accessed on 4 January 2020).

45. Petrisor, A. Interviewee, Ce îşi Comandă Românii cel mai des Prin Aplicaţiile de Livrare de Mâncare [Interview]. 5 May 2019. Available online: https://www.businessmagazin.ro/actualitate/ce-isi-comandaromanii-cel-mai-des-prin-aplicatiile-de-livrare-de-mancare-18140488?fbclid=IwAR1iruJY_3n062An1pN_ imW6T2e3KaTfEExadbbhkE2ZrtkQtjb2Eq8KX3Q (accessed on 12 January 2020).

46. Buican, A.; Românii Comandă tot mai Multă Mâncare Online. Piaţa de Food Ordering Online Crește Datorită Generației Millennials. Capital. 4 June 2018. Available online: https://www.capital.ro/romanii-comandamai-multa-mancare-online-piata-de-food-ordering.html (accessed on 18 February 2020).

47. Hulin, C.; Netemeyer, R.; Cudek, R. Can a Reliability Coefficient Be Too High? J. Consum. Psychol. 2001, 10, $55-58$.

48. RaoSoft. RaoSoftware. 2020. Available online: Raosoft.com/samplesize.html (accessed on 11 November 2019).

49. Kim, J. How to Choose the Level of Significance: A Pedagogical Note. 2015. Available online: https: //mpra.ub.uni-muenchen.de/69992/ (accessed on 6 February 2020).

(C) 2020 by the authors. Licensee MDPI, Basel, Switzerland. This article is an open access article distributed under the terms and conditions of the Creative Commons Attribution (CC BY) license (http://creativecommons.org/licenses/by/4.0/). 